\title{
The Changing Nature of the Consumer in the Digital Reality
}

Monika Jagielska1<monika.jagielska@us.edu.pl>

KATOWICE, Poland

Monika Namystowska² <mnamyslowska@wpia.uni.lodz.pl>

ŁÓDŹ, Poland

Aneta Wiewiórowska-Domagalska <aneta.wiewiorowska@uni-osnabrueck.de> OSNABRÜCK, Germany

\section{Introduction}

While it is only natural that the market, business models and commercial practices change constantly, the creation of the digital reality has had an impact on the pace and depth of the ongoing changes. The digital reality itself is also not constant - it undergoes profound and rapid transformations. Unsurprisingly, these changes exert an impact on the market actors, including on the perception of who an (average) consumer is. As the complexity of today's digital world is ever-growing, the challenges it brings about from the consumers' point of view are not static. What was incomprehensible to consumers at the dawn of the e-commerce era, and as such posed a threat to their interests, does not have to pose a similar danger now.

It is therefore clear that the market reality reshapes the notion of a consumer, as well as the model of a consumer, because they both are constructed to reflect the perils that the current market poses for consumers. To examine the transformation of the notion and model of a consumer, this article focuses on the reasons that triggered the changes in the concept of consumer, and the menaces that are decisive for distinguishing contemporary consumers in the digital world from other market players. It focuses on the process, fuelled by the digital revolution that has triggered

1 The research of Monika Jagielska leading to this paper was prepared in frame of the NCN Project 2015/17/B/HS/01416 "Protection of a weaker party to the contract".

2 The research of Monika Namysłowska leading to this paper was financed by the National Science Centre (Narodowe Centrum Nauki) in Poland on the basis of decision DEC-2018/31/B/HS5/01169. 
and/or accelerated this transformation. It transforms customers, who cease being consumers of goods and become users of goods. Consequently, consumer protection measures based on the traditional design of a sales contract are no longer sufficient to ensure the parties have an equivalent position on the market. Next, it focuses on the new types of vulnerability created by the digital environment. Further, it presents arguments to prove that the traditional legal designs, originating in sales law set in an off-line environment, require a critical analysis and, most likely, a significant reconceptualization. Finally, the analysis focuses on the consumer model and the adjustments that would be required in order to apply the EU model of an average consumer for consumers who function in the contemporary digital reality.

\section{The triggers of the change}

\subsection{Departing from sales contract}

In the second half of the 20th century, when consumer protection became a well-grounded element of legal orders, the structure of the business chains was still rather simple, and the roles of the market players were clearly defined. Each actor in the chain was either responsible for creation or for consumption ${ }^{3}-$ it was for the businesses to produce and for the final buyers to consume. Mass production, sales of finished products and the acquisition of goods for final consumption characterised the economic turnover of those times. A traditionally perceived sales contract played the role of the principal contract in legal systems that provided the basic structure for regulating this nominate contract. ${ }^{4}$ Hence, until the end of the 20th century, the orientation of law was to protect the consumer as the final purchaser of goods. ${ }^{5}$ Logically, the legal means of consumer protection were adapted to the market challenges arising in sales-related situations. Therefore, consumer law focused on ensuring the safety and the

$3<$ https://www.brandingstrategyinsider.com/2017/01/unveiling-marketings-new-defi nition-of-consumers.html\#.XWuTgy3US00> accessed 17 June 2021.

4 Reinhard Zimmermann, 'Roman Law and European Culture' (2007) 2 New Zealand Law Review.

5 John Anthony Jolowicz, 'The Protection of the Consumer and Purchaser of Goods under English Law' (1969) 32, 1 Modern Law Review. 
quality of goods on the market. Concepts such as strict product liability, ${ }^{6}$ warranty and guarantees for consumer goods ${ }^{7}$ and the right to withdraw from a contract ${ }^{8}$ were the instruments that allowed market balance to be restored in trade involving consumers.

The market, however, has changed profoundly over the last few years, along with the development of new technologies ${ }^{9}$ that have initiated a digital revolution. ${ }^{10}$ First, the role of digital content on the market has significantly increased, ${ }^{11}$ which only intensified the shift from sales to service contracts. Second, the sharing economy, ${ }^{12}$ implemented mainly via online platforms,${ }^{13}$ started to gain increasing importance. Third, consumers, whose role was initially restricted to merely consuming goods, now gained the possibility to become producers themselves, fortifying the switch from

6 William Prosser, 'The Assault Upon the Citadel (Strict Liability to the Consumer)' (1960) 69 Yale Law Journal 1099-1134; Thomas Cowan, 'Some Policy Basis of Products Liability' (1965) 17 Stanford Law Review; Spiros Simitis, Grundfragen der Produzentenhaftung (Tübingen 1965); Friedrich Kessler, 'Product Liability' (1967) 76 Yale Law Journal; Marshall Shapo, Product Liability, Cases and Materials (Mineola 1980); John Wade, 'On the Nature of Strict Tort Liability for Products' (1973) 44 Mississippi Law Journal; John. Montgomery and David Owen, 'Reflections on the Theory and Administration of Strict Tort Liability for Defective Products' (1976) 27 Santa Clara Law Review 1; Vernon Palmer, 'A General Theory of the Inner Structure of Strict Liability: Common Law, Civil Law and Comparative Law' (1989) 12 JPTL ; John Fleming, 'Mass Torts' (1994) 42 AJCL 1994.

7 Friedrich Kessler, 'The Protection of the Consumer under the Modern Sales Law' (1964) 74 Yale Law Journal; 'Disclaimer of Warranty in Consumer Sales' (1963) 77 Harv. L. R. 1963.; Addison Mueller, 'Contract of Frustration' (1969) 78 Yale Law Journal 1969; Edward Murphy, 'Another Assault upon the Citadel: Limiting the Use of Negotiable Notes and Waiver-of-Defense Clauses in Consumer Sales. Consumer Protection Symposium' (1968) 29 Ohio State Law Journal.

8 Omri Ben-Shahar and Eric A. Posner, 'The right to withdraw in contract law' (2011) 40 Journal of Legal Studies 2011.

9 Georgios Doukidis, Nikolaos Mylonopoulos and Nancy Pouloudi (eds) Social and Economic Transformation in the Digital Era (Idea Group Publishing 2004).

10 Reiner Schulze and Dirk Staudenmayer (eds) Digital Revolution: Challenges for Contract Law in Practice (Nomos 2016).

11 John B. Meisel, 'Entry into the Market for Online Distribution of Digital Content: Economic and Legal Ramifications' (2008) 5, 1 SCRIPTed: A Journal of Law, Technology and Society .

12 Daniela Selloni, New Forms of Economies: Sharing Economy, Collaborative Consumption, Peer-to-Peer Economy (Springer 2017).

13 Kateryna Stanoevska-Slabeva, Vera Lenz-Kesekamp and Viktor Suter, 'Platforms and the Sharing Economy: An Analysis' (Report from the EU H2020 Research Project Ps2Sahre) <https:/www.bi.edu/globalassets/forskning/h2020/ps2share_pla tform-analysis-paper_final.pdf $>$ accessed 20 August 2021. 
consumer to prosumer. The increasing popularity of $3 \mathrm{D}$ printing technology and the solar panel electricity production placed consumers in the position of a party that not only consumes, but also produces the goods they are interested in acquiring.

While the sharing economy was initially fuelled by the concept of creating an alternative business model, where social aspects of the business model were on an equal footing with profit making, in time it leapt back towards the traditional business concept. The increased access to goods, on a basis other than ownership, reflected (but also facilitated) the trend of slowly rejecting the concept of ownership as the leading market concept. This process lead to questions being asked about the position of the sales contract (that transfers the ownership) as the conceptual foundation for regulating contracts.

Modern consumers (known as 3.0 consumers), ${ }^{14}$ especially the younger generation, do not show a far-reaching need to own goods..$^{15}$ Such consumers prefer to have an access ${ }^{16}$ to the goods for a specific period that corresponds to their needs (taking the simplest examples of Uber $^{17}$ or Airbnb ${ }^{18}$ ), over the ownership of the goods. The market is witnessing a constant departure from traditionally understood consumption and ownership towards the temporary use of goods. The customer ceases to be a person who consumes the purchased products and becomes a user, one who needs access, ${ }^{19}$ but who is not necessarily the "final link" in the chain of the economic process. Consumer interest in the temporary use or access to goods is even more pronounced in relation to digital content (for

14 Petr Houdek, 'A Perspective on Consumers 3.0: They Are Not Better DecisionMakers than Previous Generations' (Frontiers in Psychology 2016), <https://www. ncbi.nlm.nih.gov/pmc/articles/PMC4891336> accessed 20 August 2021.

15 See: Inara Scott and Elizabeth Brown, 'Redefining and Regulating the New Sharing Economy' (2017) 19, 3 University of Pennsylvania Journal of Business Law .

16 Antonis Kalogeropoulous, 'How Younger Generations Consume News DIfeerently' (Reuters Institute, September 2019) < http://www.digitalnewsreport.org/surve y/2019/how-younger-generations-consume-news-differently> accessed 20 August 2021.

17 Elena Mazareanu, 'Uber Technologies - statistics \& facts' (Statista, 6 November 2020) <https://www.statista.com/topics/4826/uber-technologies $>$ accessed 20 August 2021.

18 Jaleesa Bustamante, 'Airbnb Statistics' (Iproperty Management, 2020) <https://ipr opertymanagement.com/airbnb-statistics $>$ accessed 20 August 2021.

19 Bronwen Morgan and Declan Kuch, 'Radical Transactionalism: Legal Consciousness, Diverse Economies, and the Sharing Economy' (2015) 42, 4 Journal of Law and Society 2015. 
example, Spotify ${ }^{20}$ or Netflix $\left.{ }^{21}\right)$. It should be assumed that this tendency will deepen ${ }^{22}$ as the sharing economy also goes along with the growing public awareness of the need for action to protect the natural environment and recourses, in which the ides of permanent usage fit very well. ${ }^{23}$ Hence, it has become necessary to reorient consumer law, still focused on protecting the final purchaser of consumer goods, into a system that protects the user, usually a long-term user, of various types of goods and services.

\subsection{Departing from the off-line world}

Although the consumer concept and the consumer model have always been built based on the consumer-trader juxtaposition, ${ }^{24}$ the digital revolution has brought about a new type of imbalance of power. For a certain moment it seemed that the digitalisation would strengthen the consumer's position against traders, as it provided consumers with instruments that addressed the very reasons that decided about qualifying them as the weaker party to a contract. First, search machines and collections of data available online gave consumers instruments to combat the informational imbalance that distinguished them from traders. Collecting and analysing data became inexpensive in terms of time and money, which levelled

20 John Porter, 'Spotify is first to 100 million paid subscribers' (The Verge, 29 April 2019) <https://www.theverge.com/2019/4/29/18522297/spotify-100-million-users -apple-music-podcasting-free-users-advertising-voice-speakers $>$ accessed 20 August 2021.

21 Seth Fiegerman, 'Netflix adds 9 million paying subsribers, but stock falls' (CNN Business 18 January 2019) <https://edition.cnn.com/2019/01/17/media/netflix-earn ings-q4/index.html $>$ accessed 20 August 2021.

22 Julie Beck, 'The Decline of the Driver's License' (The Atlantic, 22 January 2016), https://www.theatlantic.com/technology/archive/2016/01/the-decline-of-the-driver s-license/425169 <http:/www.umich.edu/ umtriswt/PDF/UMTRI-2016-4_Abstrac t_English.pdf $>$ accessed 20 August 2021.

23 Vanessa Mak and Enna Lujinovic 'Towards a Circular Economy in EU Consumer Markets - Legal Possibilities and Legal Challenges and the Dutch Example'(2019) 4 EuCML 2019; Bronwen Morgan and Declan Kuch, 'Radical Transactionalism: Legal Consciousness, Diverse Economies, and the Sharing Economy'(2015) 42, 4 Journal of Law and Society.

24 See e.g. Natali Helberger, and others 'Analysis of the applicable legal frameworks and suggestions for the contours of a model system of consumer protection in relation to digital content contracts. Final report: Comparative analysis, law \& economics analysis, assessment and development of recommendations for possible future rules on digital content contracts' (University of Amsterdam, 2011) 17 $<$ https://hdl.handle.net/11245/1.345662> accessed 5 May 2021. 
out the informational imbalance between consumers and traders. Soon, however, it turned out that the instruments that were supposed to provide objective information to consumers, actually offered them biased data. The simple search machines and comparison websites were accused of presenting results with a certain degree of bias. ${ }^{25}$ When it comes to reputational systems - the building block of the sharing economy concept based on platforms - they proved to suffer from manipulation. A report prepared for the UK's Competition and Market Authority in 2015 proved that, while consumers rely on online reviews and find them valuable, businesses write or commission fake positive reviews about themselves, businesses or individuals write or commission fake negative reviews about others, review sites "cherry-pick" positive reviews, or suppress negative reviews, which they collect or display without making it clear to readers that they are presenting a selection of reviews only. ${ }^{26}$

The ease at which news is spread also (at least temporarily) strengthened the negotiation position of the consumer (the threat of going viral). However, it soon became clear that digitalisation creates new types of imbalances that are driven by the technological advantages that the traders structurally enjoy over consumers.

Consumers have become more and more vulnerable, as traders collect increasing amounts of data about them and their preferences, which is subsequently used in sophisticated trade techniques and business models based on the AI systems. As Pasquale put it, ${ }^{27}$ "tracked even more closely by firms and governments, we have no idea of just how much of this information can travel, how it is used, or its consequences." The manipulative potential of such tools grows steadily and they become nearly impossible

25 Dirk Lewandowski, 'Living in the world of biased search engines' (2015) Online Information Review <https:/www.researchgate.net/publication/279240937_Livin g_in_a_world_of_biased_search_engines $>$ accessed 14 May 2021.

26 See: Competition \& Markets Authority, 'Online reviews and endorsements, Report on the CMA's call for information' (CMA, 19 June 2015) <https://assets.pu blishing.service.gov.uk/government/uploads/system/uploads/attachment_data/f ile/436238/Online_reviews_and_endorsements.pdf>, accessed 14 June 2021, see also: Christoph Busch, 'Crowdsourcing Consumer Confidence, How to regulate online rating and review systems in the collaborative economy' in de Franceschi (ed) European Contract Law and the Digital Single Market: the Implications of the Digital Revolution, Intersentia, (Cambridge 2016).

27 David Anthony Whitaker, 'How a Career Con Man Led a Federal Sting that Cost Google \$500 Million' (Wired, 1 May 2013), as referred to in Frank Pasquale, 'The Black Box Society: The Secret Algorithms that Control Money and Information' (2015) Harvard University Press7. 
to understand. Consumers are confronted with new types of risks, which they often do not even recognise as risks. Consumer behaviour becomes increasingly easy to affect, with traders obtaining tools that allows them to effectively control the group of consumers that they want to offer their services to (for example: medical data being used to evaluate the creditworthiness of consumers).

The frequency of use of these algorithm-based data-driven practices by the market players is also growing steadily, which is particularly endangering in the case of the large, global companies that accumulate vast amounts of data on their users. These two types of practices, combined with the size of the traders involved, leads to the creation of a unique asymmetry, known as digital asymmetry. This is understood as a structural phenomenon that affects all consumers and that cannot be overcome by the traditional means used as consumer protection measures, i.e. by providing more information. ${ }^{28}$

Another aspect of the new market reality is digital vulnerability. This concept assumes that in digital marketplaces most, if not all, consumers are potentially vulnerable. ${ }^{29}$ Digital vulnerability is defined as " $a$ universal state of defencelessness and susceptibility to (the exploitation of) power imbalances that are the result of increasing automation of commerce, datafied consumerseller relations and the very architecture of digital marketplaces." 30 Not only does digital vulnerability as a concept seems to be in opposition to the average consumer model, but it also refines the notion of a vulnerable consumer. EU consumer law does not foresee such a standard, which is why proposals are being made to amend the law accordingly. ${ }^{31}$

\section{Changes in the notion of a consumer}

Considering the depth of the current market changes, the need to reorient consumer law from being focused on protecting the final purchaser of goods into a system that protects users of various types of goods and services, usually in a long-term relation, became evident. Over the past 50 years, not only in the European Union, ${ }^{32}$ legal mechanisms have been

28 Helberger (n 14) 51.

29 ibid 5.

30 ibid 5 .

31 ibid 79.

32 Since 1985, the EU has developed a wide range of consumer protection instruments, mainly via consumer law directives; for more, see Stephen Weatherill, 
developed to protect traditional consumers. ${ }^{33}$ The fundamental question, therefore, is whether these traditional means of protection require merely an adjustment, or whether a complete change of concept is required, because the existing structure is completely inappropriate to address the challenges of the modern market.

It seems as if the most efficient choice is to focus on ensuring adequate protection for a new category of entity - users of goods (as opposed to the final consumers of goods). In situations where the sales contract is replaced by a contract for the use of goods, usually concluded for an extended period, the mechanisms of controlling the content of the contract begin to play a very important role. Contracts for the sale of consumer goods are usually concluded without complying with any formal requirements (save for situations when the law requires the observance of a certain form). In the contracts of everyday life, the parties usually reach a consensus on the basic issues, such as the price and main characteristics of the goods. Contracts for the use of goods, on the other hand, are usually more formal and are typically concluded based on standard contract terms, which is rather rare in trivial sales contracts. When such a long-lasting legal relation is created between the parties, provisions relating to the possibility of unilaterally shaping the content of a contract, and the mutual obligations of the parties, ${ }^{34}$ including liability, as well as the termination of the legal relationship, gain particular importance.

An analysis of the contractual patterns used in this type of contract indicates that they contain provisions that may be considered unfair. ${ }^{35} \mathrm{Eu}-$ ropean law provides protection against such clauses in relation to all types

EU Consumer Law and Policy (Edward Elgar Publishing 2014); Geraint Howells, Christian Twigg-Flesner and Thomas Wilhelmsson, Rethinking EU Consumer Law (Routledge 2019); Hans-wolfgang Micklitz and NorbertReich, EU Consumer Law(Intersentia 2014); Hans Schulte-Noelke, Christian Twigg-Flesner and Martin Ebers (eds) EC Consumer Law Compendium. The Consumer Acquis and its transposition in the Member States ( Sellier European Law Publisher 2008); Hans W. Micklitz, Jules Stuyck and Eevlyne Terryn (eds) Cases, Materials and Text on Consumer Law, (Oxford 2010).

33 Iain Ramsay, Consumer Law and Policy (Hart Publishing 1974); Geraint Howells and Stephen Weatherill, Consumer Protection Law (Routledge 2017); Geraint Howells, Iain Ramsay and Thomas Wilhelmsson, Handbook of Research on International Consumer Law (Elgar 2010).

34 Joanna Luzak, 'Digital age: time to say goodbye to traditional concepts' (2018) 17 EuCML.

35 Evelyne Terryn, 'The sharing economy in Belgium - a case for regulation?' (2016) 45 EuCML. 
of contracts concluded with consumers, ${ }^{36}$ though it may be worth considering which abusive clauses are characteristic for temporary use contracts, how they violate the contractual balance and then introduce such clauses to the catalogue of unfair contract terms. From a similar perspective, it would also be necessary to analyse the information obligations posed on the business, as well as the regulation of the unfair market practices.

\section{Changes in consumer model}

The changing nature of the consumer in the digital reality leads directly to questions about the parallel change of the consumer model, which is one of the fundamental concepts of EU consumer law. The consumer model is the reference point for determining whether a trader's conduct towards consumers is lawful or not. In other words, the accepted image of a consumer defines who is protected, and under what conditions. Although many consumer images exist, the basic consumer model is that of the average consumer. This roughly means that the standard of consumer protection is set by the expectations, perception capabilities and circumspection of the average consumer.

When discussing the digital reality, it is important to note that the currently applied model of the average consumer dates from pre-digital times and originates from the case-law of the Court of Justice on the proportionality of national restrictions under the free movement law. ${ }^{37}$ The origin of the average consumer model implies that its development was not based on any idea of consumer protection. The aim of the Court of Justice was to promote cross-border free trade, ${ }^{38}$ so the average consumer standard considers the interests of traders. However, it must also guarantee a high level of consumer protection, as required by Articles 114 and 169 TFEU. This is particularly important, as the consumer model has been gradually transferred to the acts harmonising the national consumer laws.

36 Council Directive 93/13/EEC of 5 April 1993 on unfair terms in consumer contracts [1993] OJ L 95/29-34.

37 C-210/96 Gut Springenheide and Tusky v Oberkreisdirektor des Kreises Steinfurt [1998], paras 30, 31. See also: Mateja Durovic, 'The Subtle Europeanization of Contract Law: The Case of Directive 2005/29/EC on Unfair Commercial Practices' (2015) 5 European Review of Private Law 715, 719.

38 Peter Rott, 'Der „Durchschnittsverbraucher" - ein Auslaufmodell angesichts personalisierten Marketings?’, (2015) 5 Verbraucher und Recht 163. 
The consumer model plays a pivotal role in Directive 2005/29/EC on unfair commercial practices (hereinafter: UCPD) which is the most powerful instrument for consumer protection, even in the new digital reality. ${ }^{39}$ It is the average consumer model that serves as a general vantage point for establishing the unfairness of a commercial practice. ${ }^{40}$ Since the Kásler case,$^{41}$ the average consumer model is used as a yardstick in the assessment of transparency of the contract terms. The average consumer model applies to food legislation, ${ }^{42}$ the conformity of goods, ${ }^{43}$ pre-contractual information disclosure ${ }^{44}$ etc. It is also visible outside the core acts of consumer law, such as intellectual property law. ${ }^{45}$

It is worth noting that the omnipresent 'average consumer' is not defined in any legal acts. It is the Court of Justice that sets out a definition of the average consumer as a consumer who is reasonably well-informed and reasonably observant and circumspect. ${ }^{46}$ Certain characteristics are therefore required from the consumer and the standard of protection is established to reflect them. The main reason for criticism is the assumption that the average consumer model refers to a kind of person that does not exist in real life. ${ }^{47}$ However, when seen as a normative standard, this

39 Stefan Scheuerer, 'Artificial Intelligence and Unfair Competition - Unveiling an Underestimated Building Block of the AI Regulation Landscape' (2021) GRUR International, 4, <https://academic.oup.com/grurint/advance-article/doi/10.1093/g rurint/ikab021/6178541> accessed 31 May 2021.

40 Articles 5-8 of the UCPD.

41 C-26/13 Kásler and Káslerné Rábai [2014] paras 74.

42 Article 5(2) of the Regulation (EC) No 1924/2006 of the European Parliament and of the Council of 20 December 2006 on nutrition and health claims made on foods [2006] OJ L404/9-25.

43 C-52/18 Fülla [2019] paras 40.

44 C-430/17 Walbusch Walter Busch [2019] paras 39.

45 C-456/19 Aktiebolaget Östgötatrafiken [2020] para. 40.

46 Recital 18 of the UCPD.

47 Vanessa Mak, The 'Average Consumer' of EU Law (in:) Dorota Leczykiewicz, Stephen Weatherill (eds.), The Involvement of EU Law in Private Law Relationships (Hart Publishing 2013) 335; Peter Rott, 'Der „Durchschnittsverbraucher“- ein Auslaufmodell angesichts personalisierten Marketings?' (2015) 5 Verbraucher und Recht 163-164; Rossella Incardona and Cristina Poncibò, 'The average consumer, the unfair commercial practices directive, and the Cognitive Revolution' (2007) 30, 1 Journal of Consumer Policy28. 
concept allows questions to be raised about the presumed expectations of an average consumer in a given situation, ${ }^{48}$ without empirical evidence. ${ }^{49}$

Under the UCPD, the basic model may be modified to the average member of a group of consumers when a practice is targeted at a particular group of consumers. ${ }^{50}$ These specific average consumers are then the yardstick to be used when assessing the unfairness of a commercial practice.

The predominance of the average consumer model does not leave vulnerable consumers unprotected. The UCPD introduces an alternative standard - the vulnerable consumer model - for consumers whose characteristics make them particularly vulnerable to an unfair commercial practice $^{51}$ or the underlying product because of their mental or physical infirmity, age or credulity. ${ }^{52}$ This definition was criticised as being too narrow, ${ }^{53}$ arbitrary, ${ }^{54}$ paternalistic and superfluous. ${ }^{55}$ The Court of Justice does not delve into the vulnerable consumer model. ${ }^{56}$ The European Commission claims, however, that, despite the wording of Article 5(3), the UCPD provides a non-exhaustive list of characteristics that make a consumer 'particularly susceptible'. ${ }^{57}$ This is followed by the 'New Consumer Agenda': "The vulnerability of consumers can be driven by social circumstances or because of particular characteristics of individual consumers or groups of consumers, such as their age, gender, health, digital literacy, numeracy or financial

48 Vanessa Mak, 'The 'Average Consumer' of EU Law' in: Dorota Leczykiewicz, Stephen Weatherill (eds) The Involvement of EU Law in Private Law Relationships (Hart Publishing 2016) 335.

49 ibid 386.

50 Article 5(2)(b) of the UCPD.

51 Recital 18 of the UCPD.

52 Article 5(3) of the UCPD. See more Eleni Kaprou, 'The legal definition of 'vulnerable' consumers in the UCPD: Benefits and limitations of a focus on personal attributes' in: Christine Riefa and Séverine Saintier (eds) Vulnerable Consumers and the Law: Consumer Protection and Access to Justice (Routledge 2021) 56-63.

53 Bram Duivenvoorde, 'The Protection of Vulnerable Consumers under the Unfair Commercial Practices Directive' (2013) 2 euvr 201371.

54 Jules Stuyck, Evelyne Terryn and Tom Van Dyck, 'Confidence through Fairness? The New Directive on Unfair Business-To-Business Commercial Practices in the Internal Market' (2006) 43, Common Market Law Review 107, 122-123.

55 Rossella Incardona and Cristina Poncibò, 'The average consumer, the unfair commercial practices directive, and the Cognitive Revolution' (2007) 30, 1 Journal of Consumer Policy 29.

56 C-853/19, STING Reality [2020] paras 48, 49.

57 Guidance on the Implementation/Application of Directive 2005/29/EC on Unfair Commercial Practices, SWD(2016) 163 final, section 2.6. 
situation." ${ }^{58}$ The shift from internal factors such as age or physical infirmity to external and situational ones is clearly visible..$^{59}$

Against this background, the question arises as to the consumer model that should be applied in the digital reality. Is it still justified to rely on an average consumer model that was defined long before the digital transformation, or has the time come to change the yardstick of consumer law to provide a high level of protection against the new challenges that consumers are facing?

It goes without saying that the digital vulnerability concept is based on valuable assumptions. Nevertheless, the new reality must not immediately lead to legal changes, especially as the process can take a long time and the outcomes do not unveil immediately. It is therefore worth considering whether an appropriate interpretation of the existing concepts, such as the average consumer model, is currently sufficient to maintain a high level of consumer protection.

The possibility of an interpretation suitable for the digital world results from the fact that the average consumer model is not static. No single average "Euro-consumer" exists. ${ }^{60}$ Recital 18 of the UCPD emphasises that the average consumer should be defined by "taking into account social, cultural and linguistic factors," and that national courts and authorities have to rely on their own faculty of judgement to determine the typical reaction of the average consumer in a given case. The relativisation of the average consumer is thus required. ${ }^{61}$

It is therefore necessary to specify how the average consumer behaves in the digital reality. Several factors should be considered, e.g. the type of new technology (e-commerce, digital content, smart contracts, AI systems

58 Communication from the Commission to the European Parliament and the Council, New Consumer Agenda. Strengthening consumer resilience for sustainable recovery, $\operatorname{COM}(2020) 696$ final, section 3.4.

59 Natali Helberger, Hans-W. Micklitz, Marijn Sax and Joanna Strycharz, Surveillance, Consent and the Vulnerable Consumer. Regaining Citizen Agency in the Information Economy (in) Natali Helberger, Orla Lynskey, Hans-W. Micklitz, Marijn Sax and Joanna Strycharz, Consumer protection 2.0. Structural asymmetries in digital consumer markets (2021), 15 <www.beuc.eu/publications/beuc-x-2021-018_e u_consumer_protection.0_0.pdf $>>$ accessed 31 May 2021.

60 This notion applied in: Sybe De Vries, 'Consumer protection and the EU Single Market rules - The search for the 'paradigm consumer' (2012) 4 Journal of Consumer and Market Law 228.

61 Thomas Wilhelmsson, 'Misleading Practices' in: Geraint Howells, Hans-W. Micklitz and Thomas Wilhelmsson, European Fair Trading Law. The Unfair Commercial Practices Directive (Ashgate 2006) 134. 
etc.), the category of the practice and product. ${ }^{62}$ Further, whether the consumer's attention is adequate to the situation, ${ }^{63}$ along with their knowledge. ${ }^{64}$ The average consumer may be not very observant or circumspect ${ }^{65}$ and their ability to act rationally should not be over-estimated. ${ }^{66}$

The average consumer test does not need empirical or mathematical in content, ${ }^{67}$ yet it allows empirical studies to be considered. For example, the assessment of the average consumer's expectations towards the application of AI systems may be influenced by a September 2020 study. This report revealed that $22 \%$ of consumers think $\mathrm{AI}$ is very little or not at all present, while $21 \%$ of consumers have never heard of AI or have no idea about its presence. ${ }^{68}$ On the other hand, this perception of AI-driven goods and services will certainly change, at least partly, in the future. The dynamic reading of averageness allows, however, socio-economic changes and developments in consumer behaviour ${ }^{69}$ to be captured and thereby to adapt the average consumer model to the changing reality.

For new technology practices, which are often based on personalisation, it is important that the average consumer model can also be personalised ${ }^{70}$ by referring to the concept of an average member of a group at whom a practice is targeted.

62 See Peter Reuss, ' $\$ 5$ UWG' in: Peter W. Heermann and Jochen Schlingloff (eds) Münchener Kommentar zum Lauterkeitsrecht (C.H.Beck 2020) 98-103.

63 Hans-W. Micklitz and Monika Namysłowska, '\$5 UWG' in: Gerald Spindler and Fabian Schuster (eds) Recht der elektronischen Medien. Kommentar (C.H.Beck 2019) 128.

64 C-673/17 Planet49 [2019] ECLI:EU:C:2019:246, Opinion of Advocate General Szupnar, 114.

65 Wilhelmsson (n 61) 132.

66 Stephen Weatherill, 'Who is the "Average Consumer"?' in: Stephen Weatherill and Ulf Bernitz (eds) The Regulation of Unfair Commercial Practices under EC Directive 2005/29. New Rules and New Techniques (Hart Publishing 2007) 133.

67 Wilhelmsson (n 61) 132.

68 The European Consumer Organisation, 'Artificial Intelligence: What consumer say. Findings and policy recommendations of a multi-country survey on AI', (2020) 6 <https://www.beuc.eu/publications/beuc-x-2020-078_artificial_intelligenc e_what_consumers_say_report.pdf $>$ accessed 5 May 2021.

69 Stefan Scheuerer, 'Ártificial Intelligence and Unfair Competition - Unveiling an Underestimated Building Block of the AI Regulation Landscape' (2021) 1 GRUR International 4.

70 Philipp Hacker, 'Manipulation by Algorithms. Exploring the Triangle of Unfair Commercial Practice, Data Protection, and Privacy Law' (2021) European Law Journal (forthcoming). 
Similarly, the notion of a vulnerable consumer can be applied if a practice/business model is geared towards the exploitation of particular vulnerabilities, understood as characteristics beyond the consumer's control. ${ }^{71}$ These consumers need a higher level of protection than others, which may still be granted.

To conclude, all three types of consumer yardstick: the average consumer, the target group and vulnerable consumer benchmark may be applied in a digital reality. The condition is that they are used reasonably, striking a balance between the expectations towards consumers' abilities and those abilities in reality. If this is the case, they provide a comparably high bar for consumer protection as the recently proposed concept of digital vulnerability.

\section{Conclusions}

The main objective of consumer law, which is to ensure a high level of protection to counterbalance the structural inequalities between consumers and traders, remains unchanged. What has changed, however, is the subject of protection - the user who needs to be protected, the reasons why they need protection and the means of that protection. On the one hand, at a conceptual level, the situation is less complicated than those times when consumer law was being created in the second half of the twentieth century. The idea of protecting the weaker party and its justification is generally approved, appropriate protective measures have been developed and traders have grown accustomed to the idea of providing adequate protection to both parties to the transaction. At the same time, however, the technological advancements, and the increasing use of AI-based, automated systems require an appropriate reaction, not only at a legislative level, but it also requires the adjustment of the enforcement tools and mechanisms (a similar intensity of technology utilisation). In addition, it should be emphasised that the existing rules, such as the rules on monitoring unfair contract terms and unfair market practices, would be able to provide users with an adequate legislative protection scheme. What is important is that the protection measures available to consumers should work effectively (i.e. also without needing a lawyer's assistance for "normal" cases) in a digital environment. In other words, as the market

71 Mateja Durovic, European Law on Unfair Commercial Practices and Contract Law (Hart Publishing 2016) 43. 
transforms itself into functioning in the digital reality, so should the system of consumer protection.

What is definitely needed is the reconsideration of the consumer concept (due to the changed market structure) and the consumer model (due to the new, specific nature and high complexity of today's digital reality). The existence of digital asymmetry and of new power imbalances cannot be denied and should be addressed by legislation (self-regulation advanced by many market sectors hardly seems an adequate response). The emergence of technology-driven challenges justifies the re-examination of the existing principles of consumer law, including the consumer model.

Ensuring a high level of consumer protection can also be achieved through an appropriate, dynamic interpretation of the 'average consumer', which protects against excessive protectionism and stigmatisation. ${ }^{72}$ This standard enables a variation in the expectations placed on the consumer ${ }^{73}$ and is future-proof because the changing nature of the consumer resulting from the changing reality can be considered. As consumers acquire a certain standard of legal and technical knowledge, the average consumer model will have to adapt. A proper benchmark of the average consumer in a digital reality may also result in consumer empowerment.

Nevertheless, as the notion of consumer and the model of the average consumer are only one element of the consumer protection system, a separate analysis should be carried out of whether the entire regulatory framework ensures an adequate protection of consumers/users in today's digital reality. ${ }^{74}$

72 See more on the stigmatisation of vulnerable consumers in Alyson Cole, All of Us Are Vulnerable, But Some Are More Vulnerable than Others: The Political Ambiguity of Vulnerability Studies, An Ambivalent Critique, Critical Horizons, Vol. 17, No 2 2016, 261-262; Gianclaudio Malgieri, Jędrzej Niklas, 'Vulnerable data subjects', Computer Law \& Security Review 37 (2020), 3.

73 Paolo Siciliani, Christine Riefa andHarriet Gamper, Consumer Theories of Harm (Hart Publishing 2019), 36.

74 See Monika Namysłowska and Agnieszka Jabłonowska, 'Artificial Intelligence and Platform Services: EU Consumer (Contract) Law and New Regulatory Developments' in: Martin Ebers, Cristina Poncibò and Mimi Zou (eds) Contracting and Contract Law in the Age of Artificial Intelligence (Hart Publishing 2021, forthcoming). 
